\title{
PEMBELAJARAN MEMBACA BAHASA MELAYU DALAM KALAN GAN PELAJAR TAMIL: KAEDAH GABUNG BUNYI KATA
}

\author{
Muhammad Saiful Haq Bin Hussin, \& Nik Hafizah Binti Ab. Rahman ${ }^{1}$ \\ Agus Syahrani $^{2}$ \\ Universiti Malaya $^{1}$ \\ Universitas Pontianak ${ }^{2}$ \\ Pos-el: ipul62@ hotmail.com
}

\begin{abstract}
Abstrak
Pembelajaran Membaca Bahasa Melayu dalam Kalangan Pelajar Tamil: Kaedah Gabung Bunyi Kata. Kajian ini bertujuan untuk menganalisis keberkesanan Kaedah Gabung Bunyi Kata (KGBK) dalam proses pengajaran dan pembelajaran membaca dalam bahasa Melayu. Hal ini diharapkan dapat membantu murid yang lemah dalam aspek penguasaan bacaan bahasa Melayu. Penyelidik memberi tumpuan kepada aspek bacaan kerana aspek bacaan merupakan aspek yang paling penting dalam penguasaan bahasa Melayu murid. Penyelidik juga akan menguji kesesuaian Kaedah Gabung Bunyi Kata sebagai satu kaedah yang digunakan dalam proses pengajaran dan pembelajaran membaca bahasa Melayu dalam kalangan murid-muridnya yang terdiri daripada pelajar berbangsa India dan mempelajari bahasa Melayu sebagai bahasa kedua bagi mereka. Selain daripada itu kajian ini dilakukan bagi melihat perkembangan dan prestasi murid setelah mengikuti Kaedah Gabung Bunyi Kata (KGBK) ini. Kajian ini dilakukan di Sekolah Jenis Kebangsaan Tamil (SJKT) Methodist Kapar di Klang Selangor. Sampel tediri daripada 40 orang murid tahap 1 yang dipilih berdasarkan tahap kecerdasan mereka. Dapatan kajian diperoleh melalui rekod pencapaian murid yang telah dilakukan selama 6 bulan iaitu dan bulan Mei hingga O ktober. Hasil dapatannya ternyata bahwa Kaedah Gabung Bunyi Kata (KGBK) ini amat sesuai untuk meningkatkan prestasi murid tersebut. Hal ini dapat dibuktikan bahawa 65 peratus bersamaan dengan 26 subjek kajian berjaya menguasai kemahiran membaca dengan lancar dan 35 peratus bersamaan 14 subjek kajian yang masih belum menguasai kemahiran bacaan dengan lancar itu memerlukan tempoh masa yang lebih lama (lebih kurang 3 bulan lagi) untuk mengguasainya.

Kata kunci: membaca, bahasa Melayu, kaedah G abung, bunyi kata
\end{abstract}

\begin{abstract}
Reading of Leaming in Malay Language of Indian Student: wond sound Combination Ruler. This study aims at analyzing the effectiveness of the Rules for Word Sound Combination (KGBK) in teaching an learning to read in Malay language. It is expected to help students who are weak in the aspect of mastering Malay literature. The researchers focus on reading aspect because the reading aspect is the most important aspect in student's learning Malay language. The researchers will also test the suitability of KGBK as a method used in the process of teaching and learning to read in the Malay language of the students consisting of Indian students learning Malay language as a second language for them. In addition, this study was conducted to monitor the progress and performance of students after attending KGBK. This study was conducted at the Tamil Nationality School (SJKT) Methodist Kapar in Klang Selangor. The sample consists of 40 students at level I who were selected based on the level of their intelligence. Findings were obtained through the records of student achievement that has been done for six months from the months of May to October. Findings show that KGBK is particularly suitable to enhance the performance of the students. It can be proved that 65 percent which is equal to 26 subjects who have yet to master the skill of reading fluently requires a longer period of time (about 3 months) to master it.
\end{abstract}

Keywords: reading, Malay language, rules for combining, word sound 